\title{
Oxygen Supply and Wastewater Treatment in Subsurface-Flow Constructed Wetland Mesocosm: Role of Plant Presence
}

\author{
Chan Dong1,2*, Ying-Hao Huang ${ }^{3}$, Shun-Cai Wang², Xin-Hua Wang ${ }^{4}$ \\ ${ }^{1}$ College of Applied Chemistry, Nanjing Polytechnic Institute, Nanjing, P.R. China \\ ${ }^{2}$ College of Water Conservancy and Hydropower Engineering, Hohai University, Nanjing, P.R. China \\ ${ }^{3}$ Geotechnical Engineering Department, Nanjing Hydraulic Research Institute, Nanjing, P.R. China \\ ${ }^{4}$ Jining Nansihu Lake Constructed Wetland Management Office, Jining, P.R. China
}

Received: 14 May 2015

Accepted: 10 December 2015

\begin{abstract}
Constructed wetlands have been the focus of increasing international interest because of their low maintenance, extent, efficiency and eco-friendly character. However, there is a debate about the importance of vegetation for wastewater treatment in constructed wetlands. The amounts of pollutants taken up by plants are generally low. However, plants can stimulate pollutant removal by the release of root oxygen. As one oxygen source (others may include inflow carrying of oxygen and aeration), the role of plants in pollutant removal remains unclear. This study investigated the effect of the "dischargeable oxygen release rate" on organic matter and nitrogen removal using an "in-situ test" method. In addition, the constructed wetlands were operated in a conventional way, with several oxygen sources playing a role, including inflow carrying of oxygen, aeration and oxygen release from the roots of plants. The maximum rates of dischargeable oxygen release were $23.7 \mu \mathrm{mol} / \mathrm{g} \cdot \mathrm{h}$ and $72.7 \mu \mathrm{mol} / \mathrm{g} \cdot \mathrm{h}$ at hydraulic loading rates of $6.8 \mathrm{~mm} / \mathrm{h}$ and $17.0 \mathrm{~mm} / \mathrm{h}$, respectively. The percentage contributions of plant roots to $\mathrm{BOD}_{5}$ removal were $0-18.2 \%$ and $1.2-24.8 \%$, respectively, at the two hydraulic loading rates. For nitrogen removal, the corresponding percentage ranges were $0.4-21.7 \%$ and $4.0-23.5 \%$, respectively. Therefore, the role of vegetation should not be ignored in the process of wastewater purification in constructed wetlands. Root oxygen release and pollutant removal were influenced by light and hydraulic loading rates.
\end{abstract}

Keywords: vegetation, constructed wetlands, oxygen, hydraulic loading rates

\section{Introduction}

Constructed wetlands (CW) exhibit great ecological and environmental advantages in addition to their water treatment efficiency and natural appearance [1-3]. CWs are increasingly used around the world for the treatment of domestic wastewater, industrial effluents, landfill leachate, polluted river water, and stormwater runoff, and more [2, 4-6]. CWs are inexpensive, easy to operate, and consume low energy [7].

*e-mail: chan_dong@163.com 
Plants, one of the primary CW components [7], can influence the wetland treatment performance by several processes. Firstly, wetland plants enhance the abundance and diversity of microorganisms in the rhizosphere by increasing available surface area for bacterial attachment and growth [8]. Secondly, the roots of wetland plants exude a range of degradable organic compounds (including sugars, organic acids, and amino acids), which can especially provide a continuing supply of carbon for denitrification bacteria in wetland systems. Thirdly, wetland plants absorb nutrients into their tissues directly [9], and other contaminants such as heavy metals and micro-pollutants $[10,11]$. Fourthly, the existence of plants is thought to increase and stabilize hydraulic conductivity in CW [12]. Finally, plant roots improve oxygen conditions, thereby supporting the aerobic processes in $\mathrm{CW}$ in flooded conditions [7]. Otherwise, wetland plants play roles as a habitat provider for microbes and fauna, and form topography and landscape in wetland ecosystems [13].

Zhang et al. quantified oxygen release by plants in different stages of the wetland plant life cycle [14]. Results obtained from one year of measurement in subsurface wetland microcosms demonstrated that oxygen release from Phragmites australis varied from 108.89 to $404.44 \mathrm{mg} \mathrm{O} / \mathrm{m}^{2} / \mathrm{d}$ during the different periods from budding to dormancy. Plant species, substrate types, and culture solutions had a significant effect on the capacity of oxygen release of wetland plants. Oxygen supply by wetland plants was estimated to potentially support a removal of $300.37 \mathrm{mg} \mathrm{COD} / \mathrm{m}^{2} / \mathrm{d}$ or $55.87 \mathrm{mg}$ $\mathrm{NH}_{4}-\mathrm{N} / \mathrm{m}^{2} / \mathrm{d}$. According to oxygen balance analysis, oxygen release by plants could provide $0.43-1.12 \%$ of biochemical oxygen demand in typical subsurface-flow constructed wetlands. This demonstrates that oxygen release of plants may be a potential source for pollutant removal, especially in low-loaded CW. This is coincident with some previous conclusions that plants do not release enough oxygen into the rhizosphere for removing pollutants - especially in subsurface flow CW [15]. However, according to Kadlec and Wallace [16], oxygen supply (mainly from plants, atmosphere, or artificial aeration) plays a key role in CW pollutant removal [12].

Above all, the role of wetland plants in supplying oxygen via the roots to the soil matrix is the subject of considerable debate. Also, the contribution of oxygen derived from the roots of wetland plants to the removal of organic matter and nitrogen remains unclear. Thus, the contribution of vegetation to wastewater treatment in constructed wetlands needs further investigation. In the present study, basic variation in the released oxygen potentially able to be used by microorganisms, named the "dischargeable oxygen release rate," was examined using a new method, which can test the oxygen release rate in situ. The proportion of pollutant removal that involved the consumption of oxygen derived only from roots was investigated and contrasted with that using oxygen from a variety of sources. The overall aim was to provide a better understanding of the role of vegetation in wastewater treatment in constructed wetlands.

\section{Materials and Methods}

\section{Experimental Materials and Procedures}

The model wetland used in this study was a subsurface vertical flow constructed wetland (CW). A mesocosm was prepared using a perspex column $150 \mathrm{~mm}$ in diameter and 1,000 $\mathrm{mm}$ high. The mesocosm was filled with 2-5 $\mathrm{mm}$ scoria as the substrate to a depth of $900 \mathrm{~mm}$, giving an average porosity value of 0.46 . Inlets and outlets at different heights of the mesocosm (model CW) were set up (Fig. 1). Young Typha orientalis Presl. plants collected from a natural wetland located in Xuanwu Lake, Nanjing, China, were planted in the wetland mesocosm. It was exposed to the open air with natural light outside the laboratory building.

Ammonium chloride, potassium dihydrogen phosphate, and glucose were used as the sources of ammonium and organic matter. They were mixed with tap water to prepare the artificial wastewater [17]. The wastewater was pumped into a holding tank from which the mesocosm was supplied. Two hydraulic loading rates (HLR) were used: $6.8 \mathrm{~mm} / \mathrm{h}$ and $17 \mathrm{~mm} / \mathrm{h}$. The model CW was operated for one year. When the mesocosm reached its steady state after the start-up period, samples of influent and effluent were collected every $2 \mathrm{~h}$. The samples were then analyzed for $\mathrm{DO}, \mathrm{BOD}_{5}$, and ammoniacal-nitrogen according to the Standard Methods for Examination of Water and Wastewater[18].

\section{Release Rate of Root Oxygen in situ and Water Sampling}

To measure the release rate of root oxygen, the surface of the substrate (scoria) was covered with Vaseline to prevent re-aeration from the atmosphere. For the purpose of examining the dischargeable oxygen release rate of the wetland plants, oxygen-free water was prepared using

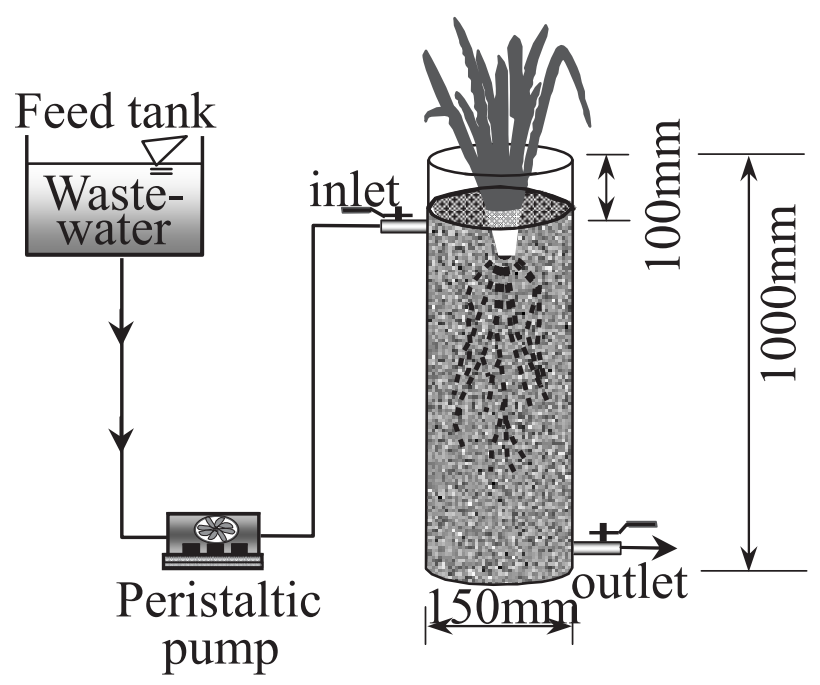

Fig. 1. Schematic description of the vertical subsurface flow CW system. 
hyposulfite. The DO concentration was tested frequently, and kept between 0 and $0.5 \mathrm{mg} / \mathrm{l}$. The oxygen in the blank influent (without pollutants) of the wetland mesocosm was carefully pre-monitored. Some oxygen was then released from the root systems of plants in the process of photosynthesis. Two hours later, the oxygen in the effluent was examined. The mass difference of oxygen was used to calculate the dischargeable oxygen release rate.

A potential difficulty with this measurement is interference from oxygen in the air. To deal with this, the following procedure was used: First, the volume of the blank influent was carefully controlled and the DO concentration pre-monitored. Second, before the blank influent was introduced to the mesocosm, $\mathrm{O}_{2}$ in the pore space of the substrate was replaced with $\mathrm{N}_{2}$. The influent was then added rapidly into the mesocosm. Two hours later, the mesocosm was carefully drained using a vacuum-pump. At the same time, $\mathrm{N}_{2}$ was injected into the mesocosm to prevent re-aeration. Finally, the volume and DO concentration of the effluent of the wetland mesocosm were measured, which allowed calculation of the difference in the $\mathrm{O}_{2}$ mass over the 2-h period. To

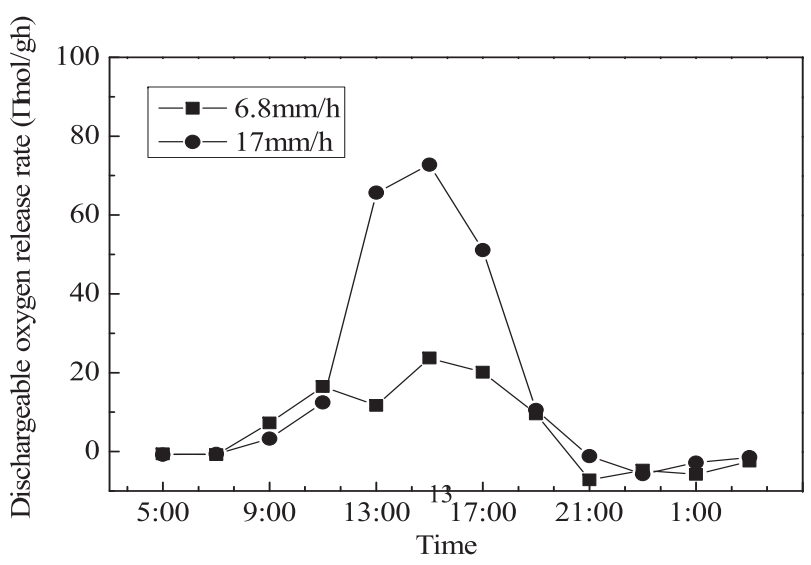

Fig. 2. Diurnal fluctuation in the dischargeable oxygen release rate at two hydraulic loading rates.

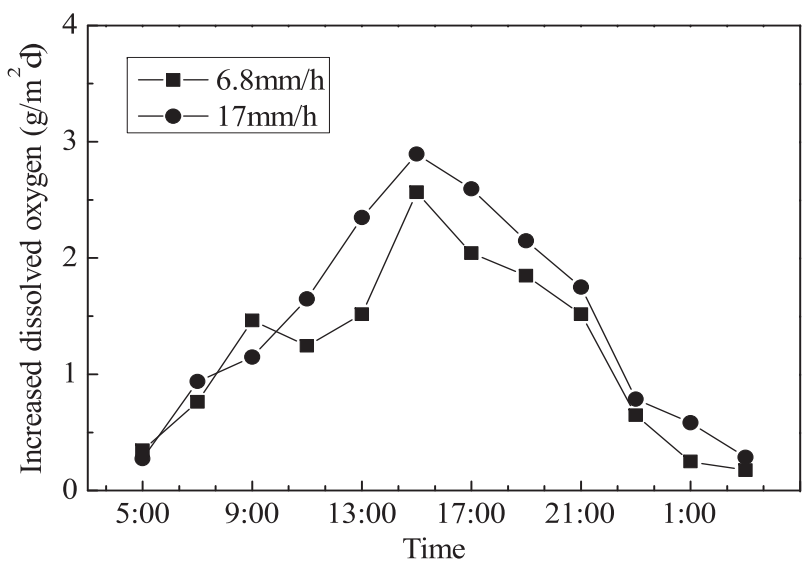

Fig. 3. Diurnal fluctuation in concentrations of dissolved oxygen in substrate water at two hydraulic loading rates. investigate the effect of vegetation on microbial processes by increasing oxygen concentrations in the rhizosphere, blank influent was added instead of wastewater, and the samples were then analyzed for $\mathrm{DO}, \mathrm{BOD}_{5}$, and ammoniacal-nitrogen. Also, to better understand the role of vegetation, conventional operation of the CW system was carried out, incorporating three oxygen sources, reaeration, influent DO and root oxygen release. In this conventional operating mode, wastewater was pumped into the mesocosm continuously and water samples were collected from the columns every $2 \mathrm{~h}$.

\section{Results}

Fig. 2 shows the typical daily change in the dischargeable oxygen release rate, which could be used by microorganisms. Oxygen release increased gradually in the morning with increasing light intensity. However, a decrease in the oxygen release rate occurred following the decreased light intensity in the afternoon. At night, the

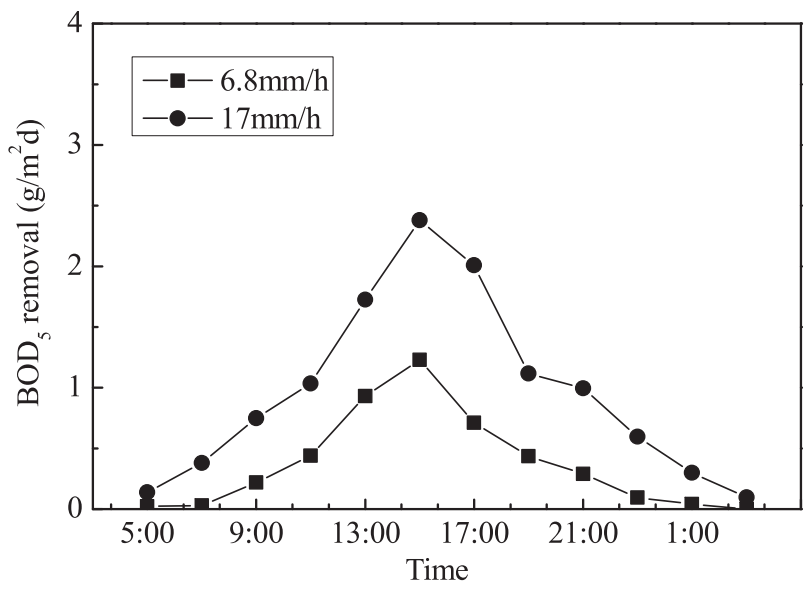

Fig. 4. Diurnal fluctuation in $\mathrm{BOD}_{5}$ removal at two hydraulic loading rates.

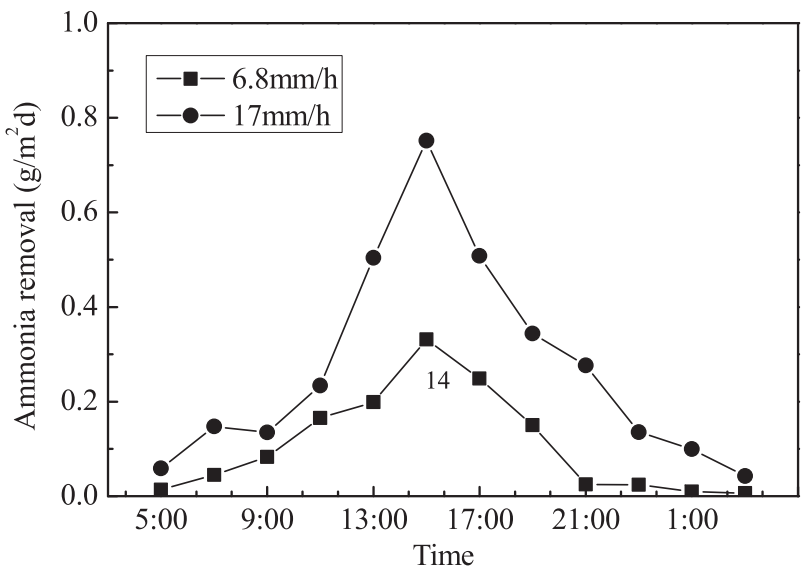

Fig. 5. Diurnal fluctuation in ammonia removal at two hydraulic loading rates. 
oxygen release rate was lower than zero. The mesocosms were operated at hydraulic loading rates of $6.8 \mathrm{~mm} / \mathrm{h}$ and $17 \mathrm{~mm} / \mathrm{h}$, and the dischargeable oxygen release rates were in the range of -7.2-23.7 $\mu \mathrm{mol} / \mathrm{gh}$ and $-5.7-72.7$ $\mu \mathrm{mol} / \mathrm{gh}$, respectively. The maximum oxygen release rate was observed during the daytime at 15:00 $\mathrm{h}$, and the dischargeable oxygen release rate was enhanced at the higher hydraulic loading rate.

Fig. 3 illustrates the diurnal changes in the DO concentration of the substrate water samples in the CW mesocosm. In the substrate water, DO concentrations fluctuated, ranging from $0.2-2.6 \mathrm{~g} / \mathrm{m}^{2} \mathrm{~d}$ and $0.3-2.9 \mathrm{~g} / \mathrm{m}^{2} \mathrm{~d}$ at hydraulic loading rates of $6.8 \mathrm{~mm} / \mathrm{h}$ and $17 \mathrm{~mm} / \mathrm{h}$, respectively, because of the oxygen released by the root systems of the wetland plants.

The daily changes in the removal of organic matter, measured as $\mathrm{BOD}_{5}$ concentrations, are presented in Fig. 4. The two hydraulic loading rates $(6.8 \mathrm{~mm} / \mathrm{h}$ and $17 \mathrm{~mm} / \mathrm{h})$ had average $\mathrm{BOD}_{5}$ concentrations of the influent water of $41.8 \mathrm{mg} / \mathrm{l}$ and $42.7 \mathrm{mg} / \mathrm{l}$, respectively, and $\mathrm{BOD}_{5}$ removals were in the range of $0-1.2 \mathrm{~g} / \mathrm{m}^{2} \mathrm{~d}$ and $0.1-2.4 \mathrm{~g} / \mathrm{m}^{2} \mathrm{~d}$, respectively. More importantly, there was a significant

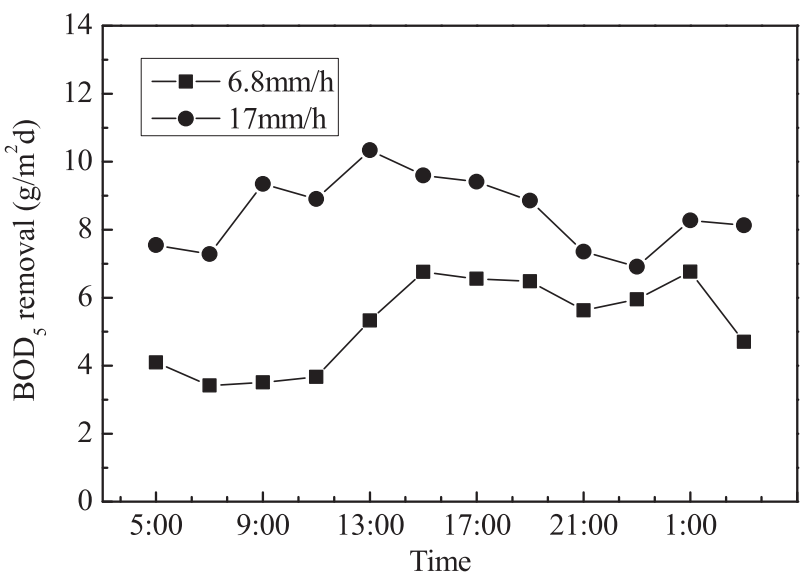

Fig. 6. Diurnal fluctuation of $\mathrm{BOD}_{5}$ removal in conventional systems.

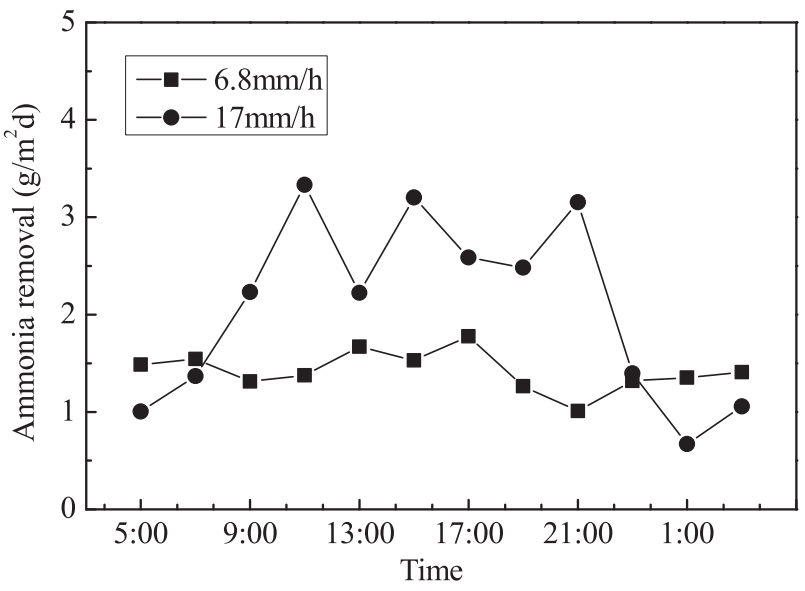

Fig. 7. Diurnal fluctuation of ammonia removal in conventional systems. difference in $B O D_{5}$ removal between day and night, being higher during the daytime, and following a unimodal distribution pattern. The removal of organic matter thus followed the same diurnal pattern as the release of root oxygen. The oxygen consumed by the microbial population in the process of organic matter degradation only came from release by the roots of the wetland plants. The released oxygen influenced nitrification similarly, with the diurnal variation in ammonia removal following the same trends as organic matter removal (Fig. 5).

When the constructed wetlands were operated conventionally, oxygen from several sources (such as re-aeration, influent DO, and root oxygen release) was introduced into the system. Wastewater was taken into the top layer by a peristaltic pump and discharged from the bottom. The reaction was not interrupted in the process of sampling. The two different hydraulic loading rates $(6.8 \mathrm{~mm} / \mathrm{h}$ and $17 \mathrm{~mm} / \mathrm{h})$ had average $\mathrm{BOD}_{5}$ concentrations of the influent of $47.3 \mathrm{mg} / \mathrm{l}$ and $26.1 \mathrm{mg} / \mathrm{l}$, and the average $\mathrm{BOD}_{5}$ removals were $5.2 \mathrm{~g} / \mathrm{m}^{2} \mathrm{~d}$ and $8.5 \mathrm{~g} / \mathrm{m}^{2} \mathrm{~d}$, respectively (Fig. 6). More organic matter was removed from the systems at the hydraulic loading rate of $17 \mathrm{~mm} / \mathrm{h}$.

Fig. 7 illustrates the diurnal fluctuation of ammonia removal in the constructed wetlands. The average

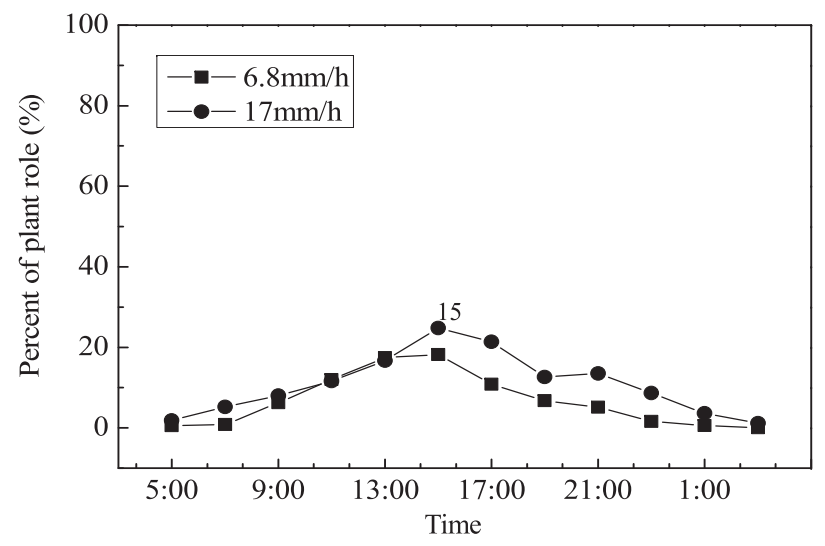

Fig. 8. The proportion of $\mathrm{BOD}_{5}$ removal involving consumption of oxygen derived only from roots.

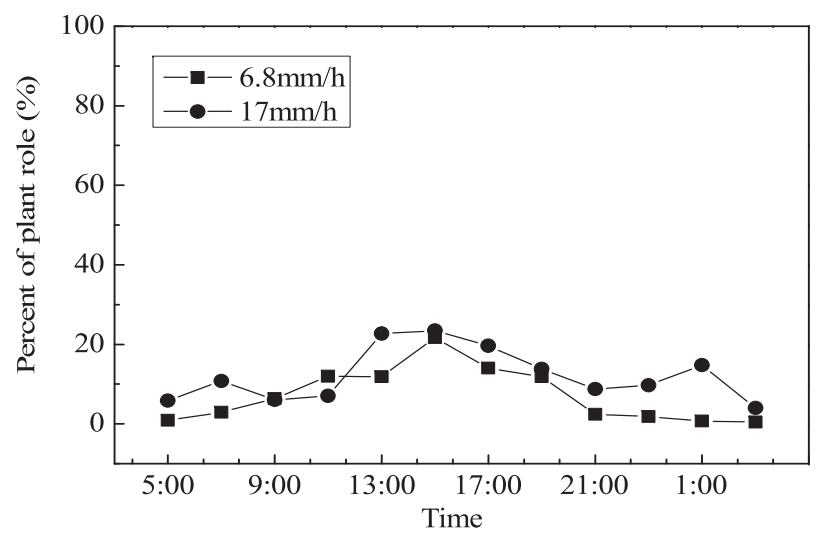

Fig. 9. The proportion of ammonia removal involving consumption of oxygen derived only from roots. 
ammonia concentrations of influent were $17.2 \mathrm{mg} / \mathrm{l}$ and $18.5 \mathrm{mg} / \mathrm{l}$ for the two different hydraulic loading rates of $6.8 \mathrm{~mm} / \mathrm{h}$ and $17 \mathrm{~mm} / \mathrm{h}$, respectively. The data show that the daily change of ammonia removal at the higher hydraulic loading rate $(17 \mathrm{~mm} / \mathrm{h})$ was more similar to the observed variation in the rate of root oxygen release.

The data from Figs 4 and 6 were used to calculate the percentage of organic matter removal contributed by the wetland plants, which is shown in Fig. 8. It is interesting that it was possible to detect the important role of plants. The percentage contributions of plant roots to $B O D_{5}$ removal were in the range of $0-18.2 \%$ and $1.2-24.8 \%$ for the two different hydraulic loading rates of $6.8 \mathrm{~mm} / \mathrm{h}$ and $17 \mathrm{~mm} / \mathrm{h}$, respectively. Average percentage contribution values were $6.7 \%$ and $10.8 \%$, respectively, in one daynight period. At the same time, the percentage contribution of plant roots to ammonia degradation was investigated (Fig. 9). Percentage contributions were in the range of $0.4-21.7 \%$ and $4.0-23.5 \%$ for the two different hydraulic loading rates of $6.8 \mathrm{~mm} / \mathrm{h}$ and $17 \mathrm{~mm} / \mathrm{h}$, respectively, with average percentage contributions of $7.3 \%$ and $12.2 \%$, respectively. The maximum percentage contribution was observed during the daytime at 15:00 $\mathrm{h}$. The percentage contribution of oxygen derived from roots to both organic matter and ammonia removal was higher at the higher hydraulic loading rate of $17 \mathrm{~mm} / \mathrm{h}$.

\section{Discussion}

In this study examined the rate of dischargeable oxygen release from the roots of a wetland plant, Typha orientalis Presl. Oxygen release rates (Fig. 2) were much lower than those reported for other wetland plant species. An oxygen release rate of $148-798 \mu \mathrm{molO}_{2} / \mathrm{gDW}_{\text {root }}$ h for M. spicatum and P. crispus was reported by Laskov [19]. This difference in the release rate of root oxygen compared with the higher values obtained in previous studies can be explained by their use of a titanium (Ш) redox buffer. The titanium (Ш) redox buffer could scavenge the oxygen as it was released, preventing it from being reabsorbed by the respiring root tissue. Sorrell and Armstrong (1994) showed that when titanium citrate was used in a closed chamber, the rate of root oxygen release was $>80$ times higher than in the nutrient solutions. However, the oxygen detected in this study was only a fraction of the total released oxygen. Dong et al. (2011) showed that only $35.0 \%$ and $8.7 \%$ of the oxygen released by roots was used in the degradation of organic matter and nitrification, respectively, through heterotrophic bacterial activity. A greater amount of $55.8 \%$ was used for root respiration, because the oxygen released from one part of the root system was reabsorbed by another part [20].

The rate of release of root oxygen increased with increasing light intensity and hydraulic loading rates. Thus light intensity is a major factor influencing oxygen release. The moved wastewater in the $\mathrm{CW}$ can stimulate root oxygen release by moving oxygen far away from the rhizosphere [1]. These plants alter the dissolved oxygen (DO) concentrations of water. Furthermore, increased oxygen is beneficial for removing nitrogen and organic matter. The DO is usually considered to be the limiting factor. Nitrification, in most cases, is regarded as the pathway to remove ammonia in the biological processes. In this pathway, ammonia is oxidized to nitrite by ammoniaoxidizing bacteria (AOB) and further oxidized to nitrate by nitrite-oxidizing bacteria (NOB). In nitrification, about $4.57 \mathrm{mgO} / \mathrm{mgNH}_{4}^{+}-\mathrm{N}$ is consumed by the nitrifiers in stoichiometric proportions [21]. Aerobic degradation is the predominant process of organic matter removal.

Currently, there is discussion about the importance of wetland plants. Bezbaruah [22] noted that plants did not release enough oxygen to meet the total oxygen demand of bulk wastewater. However, Chen et al. showed a significant enhancement by vegetation in the removal of the low chlorinated hydrocarbon MCB, which was probably because of aerobic MCB degraders benefiting from the oxygen released by plant roots [23, 24]. Vegetation principally creates additional aerobic environments for microbial populations through oxygenating the sediments around root hairs [25]. Relevant measurements of gases in the rhizosphere and soil matrix are very difficult to make [26-29]. In the present study, a new method in accord with actual conditions was investigated, which better describes the variations in oxygen release and pollutant removal in situ. The results showed that the percentage contribution of plant roots to $\mathrm{BOD}_{5}$ removal was in the range of $0-18.2 \%$ and $1.2-24.8 \%$ at two different hydraulic loading rates of $6.8 \mathrm{~mm} / \mathrm{h}$ and $17 \mathrm{~mm} / \mathrm{h}$, respectively. The corresponding ranges for ammonia removal were $0.4-21.7 \%$ and $4.0-23.5 \%$, respectively. Thus, although plants are not the most important factor in wastewater treatment, the role of vegetation cannot be ignored. And the dischargeable oxygen release rate exhibits a diurnal periodicity occurring during daytime. It is beneficial to the process of nitrification and denitrification for nitrogen removal. The capacity of root oxygen release varies in accordance with several factors such as growth conditions, including light intensity, air and water temperature, wind velocity, air pressure, humidity, redox state, $\mathrm{pH}$, oxygen concentration, substrate type, culture solutions, and chemical characteristics [15], and this varies in ecophysiological and morphological features of wetland plants, such as aerenchyma, porosity, age, plant states, biomass, length, and diameter [30]. The results of the present study indicated that higher hydraulic loading rates can enhance their importance by increasing the release rate of root oxygen. The role of plants in CWs is not merely oxygen release to rhizosphere, but wetland plants can influence the wetland treatment performance by other processes. First, they enhance the abundance and diversity of microorganisms in the rhizosphere by increasing the available surface area for bacterial attachment and growth. Second, wetland plants can take up nutrients for plant growth and reproduction, and other contaminants such as heavy metals and micro-pollutants [12]. 


\section{Conclusions}

The dischargeable oxygen release rates were in the range of -7.2-23.7 $\mu \mathrm{mol} / \mathrm{gh}$ and -5.7-72.7 $\mu \mathrm{mol} / \mathrm{gh}$ at two different hydraulic loading rates of $6.8 \mathrm{~mm} / \mathrm{h}$ and 17.0 $\mathrm{mm} / \mathrm{h}$, respectively. The dischargeable oxygen release rates depended largely on light intensity, and exhibited a diurnal periodic variation. The percentage contributions of plant roots to organic matter removal were in the range of $0-18.2 \%$ and $1.2-24.8 \%$, respectively, at the two hydraulic loading rates. The corresponding ranges for ammonia removal were $0.4-21.7 \%$ and $4.0-23.5 \%$, respectively. Therefore, the role of vegetation should not be ignored in the process of wastewater purification in constructed wetlands. The diurnal variation of dischargeable oxygen release rates is a benefit to the process of nitrification and denitrification for nitrogen removal. Root oxygen release and pollutant removal were influenced by light and hydraulic loading rates.

\section{Acknowledgements}

This work was financially supported by the National Natural Science Foundation of China (51308184 and 51209142), the National Science and Technology Ministry (ID: 2012BAC04B01), humanities and social science projects of Nan Jing College of Chemical Technology (NJCC-2014-YB-05), a research project of Nanjing Polytechnic Institute (NHKY-2015-03), and Jiangsu Students' Project for Innovation and Entrepreneurship Training (201512920006Y).

\section{References}

1. DONG C., ZHU W., GAO M., ZHAO L.F., HUANG J.Y. and ZHAO Y.Q. Diurnal Fluctuations in Oxygen Release from Roots of Acorus calamus Linn in a Modeled Constructed Wetland. J. Environ. Sci. Health., Part A. 46, 224, 2011.

2. MADERA P.C.A., PEŇA M.R., PEŇA E.J., LENS P.N.L. $\mathrm{Cr}(\mathrm{VI})$ and COD removal from landfill leachate by polyculture constructed wetland at a pilot scale. Environ. Sci. Pollut. Res. 1, 2014.

3. VYMAZAL J. The use of constructed wetlands with horizontal subsurface flow for various types of wastewater. Ecol. Eng. 35, 1, 2009.

4. MESQUiTA M.C., ALBUQUERQUE A., AMARAL L., NOGUEIRA R. Effect of vegetation on the performance of horizontal subsurface flow constructed wetlands with lightweight expanded clay aggregates. Int. J. Environ. Sci. Technol. 10, 433, 2013.

5. XU D., LI Y., and HOWARD A. Influence of earthworm Eisenia fetida on removal efficiency of $\mathrm{N}$ and $\mathrm{P}$ in vertical flow constructed wetland. Environ. Sci. Pollut. Res. 20, 5922, 2013.

6. BIALOWIEC A., DAVIES L., ALBUQUERQUE A., RANDERSON P. Nitrogen removal from landfill leachate in constructed wetlands with reed and willow: redox potential in the root zone. J. Environ. Manag. 97, 22, 2012.

7. WANG Q., XIE H.J., NGO H.H., GUO W.S., ZHANG J., LIU C., LIANG S., HU Z., YANG Z.C., ZHAO C.C.
Microbial abundance and community in subsurface flow constructed wetland microcosms: role of plant presence. Environ. Sci. Pollut. Res. 1, 2015.

8. MENON R., JACKSON C.R., HOLLAND M.M. The Influence of Vegetation on Microbial Enzyme Activity and Bacterial Community Structure in Freshwater Constructed Wetland Sediments. Wetlands. 33, 365, 2013.

9. LIU J.G., ZHANG W., QU P., WANG M.X. Cadmium tolerance and accumulation in fifteen wetland plant species from cadmium-polluted water in constructed wetlands. Front. Environ. Sci. Eng. 1, 2014.

10. TEUCHIES J., DE J.M., MEIRE P., BLUST R., BERVOETS L., Can acid volatile sulfides (AVS) influence metal concentrations in the macrophyte Myriophyllum aquaticum? Environ. Sci. Technol. 46, 9129, 2012.

11. HUANG J.C., PASSEPORT E., TERRY N. Development of a constructed wetland water treatment system for selenium removal: use of mesocosms to evaluate design parameters. Environ. Sci. Technol. 46, 12021, 2012.

12. ZHANG J., WU H.M., HU Z., LIANG S., FAN J.L. Examination of oxygen release from plants in constructed wetlands in different stages of wetland plant life cycle. Environ. Sci. Pollut. Res. 21, 9709, 2014.

13. HONG M.G., SON C.Y., and KIM J.G. Effects of interspecific competition on the growth and competitiveness of five emergent macrophytes in a constructed lentic wetland. Paddy Water Environ. 12, 193, 2014.

14. VILLAMAR C.A., NEUBAUER M.E., and VIDAL G. Distribution and Availability of Copper and Zinc in a Constructed Wetland Fed with Treated Swine Slurry from an Anaerobic Lagoon. Wetlands. 34, 583, 2014.

15. BEZBARUAH A.N., ZHANG T.C. pH, Redox, and oxygen microprofiles in rhizosphere of bulrush (Scirpus validus) in a constructed wetland treating municipal wastewater. Biotechnol. Bioeng. 88, 60, 2004.

16. KADLEC R.H., WALLACE S.D. Treatment Wetlands, 2nd edn. CRC Press, Boca Raton, USA. 2009.

17. SASIKALA S., TANAKA N., WAH H.S.Y.W. and JINADASA K.B.S.N. Effects of water level fluctuation on radial oxygen loss, root porosity, and nitrogen removal in subsurface vertical flow wetland mesocosms. Ecol. Eng. 35, 410, 2009.

18. ADMINISTRATION S.E.P. Standard Methods for Water and Wastewater Monitoring and Analysis, 4th edition; China Environmental Science Press: Beijing, 200, 2002.

19. LASKOV C., HORN O. and HUPFER M. Environmental factors regulating the radial oxygen loss from roots ofMyriophyllum spicatum and Potamogeton crispus. Aquat. Bot. 84, 333, 2006.

20. DONG C., ZHU W., ZHAO Y.Q. and GAO M. Diurnal fluctuations in root oxygen release rate and dissolved oxygen budget in wetland mesocosm. Desalin. 272, 254, 2011.

21. YU X., QI Z.H., ZHANG X.J., YU P., LIU B., ZHANG L. and FU L. Nitrogen loss and oxygen paradox in full-scale biofiltration for drinking water treatment. Water Res. 41, $1455,2007$.

22. BEZBARUAH A.N., ZHANG T.C. Quantification of Oxygen Release by Bulrush (Scirpus validus) Roots in a Constructed Treatment Wetland. Biotechnol. Bioeng. 89, 308, 2004.

23. CHEN Z., WU S., BRAECKEVELT M., PASCHKE H., KÄSTNER M., KÖSER H. and KUSCHK P. Effect of vegetation in pilot-scale horizontal subsurface flow constructed wetlands treating sulphate rich groundwater contaminated with a low and high chlorinated hydrocarbon. Chemosphere. 89, 724, 2012. 
24. ELSAESSER D., BLANKENBERG A.B., GEIST A., MæHLUM T. and SCHULZ R. Assessing the influence of vegetation on reduction of pesticide concentration in experimental surface flow constructed wetlands: Application of the toxic units approach. Ecol. Eng. 37, 955, 2011.

25. HAMMER D.A. Designing constructed wetlands systems to treat agricultural nonpoint source pollution. Ecol. Eng. 1, 49, 1992.

26. RANDERSON P.F., JORDAN G. and WILLIAMS H.G. The role of willow roots in sub-surface oxygenation of vegetation filter beds-mass spectrometer investigations in Wales, U.K. Ecohydrol. Hydrobiol. 7, 255, 2007.

27. BRIX H. Do macrophytes play a role in constructed treatment wetlands? Water Sci. Technol. 35, 11, 1997.
28. 28. australis- a preliminary study of soil oxidising sites and internal gas transport parthways. New Phytologist. 108, 373, 1988.

29. ARMSTRONG W., COUSINS D., ARMSTRONG J., TURNER D.W. and BECKETT P.M. Oxygen Distribution in Wetland Plant Roots and Permeability Barriers to Gasexchange with the Rhizosphere: a Microelectrode and Modelling Study with Phragmites australis. Ann. Bot. 86, 687, 2000.

30. CHENG X.Y., WANG M., ZHANG C.F., WANG S.Q., CHEN Z.H. Relationships between plant photosynthesis, radial oxygen loss and nutrient removal in constructed wetland microcosms. Biochem. S yst. Ecol. 54, 299, 2014. 
